\title{
Trifurcatia flabellata n. gen. n. sp., a putative monocotyledon angiosperm from the Lower Cretaceous Crato Formation (Brazil)
}

\author{
Barbara Mohr ${ }^{1}$ \& Catarina Rydin ${ }^{2}$
}

With 4 figures

\begin{abstract}
The Lower Cretaceous Crato Formation (northeast Brazil) contains plant remains, here described as Trifurcatia flabellata n. gen. and n. sp., consisting of shoot fragments with jointed trifurcate axes, each axis bearing a single amplexicaul serrate leaf at the apex. The leaves show a flabellate acrodromous to parallelodromous venation pattern, with several primary, secondary and higher order cross-veins. This very unique fossil taxon shares many characters with monocots. However, this fossil taxon exhibits additional features which point to a partly reduced, and specialized plant, which probably enabled this plant to grow in (seasonally) dry, even salty environments.
\end{abstract}

Key words: Plant fossils, Early Cretaceous, jointed axes, amplexicaul serrate leaves, Brazil.

\section{Zusammenfassung}

In der unterkretazischen Cratoformation (Nordostbrasilien) sind Pflanzenfossilien erhalten, die hier als Trifurcatia flabellata $\mathrm{n}$. gen. n. sp. beschrieben werden. Sie bestehen aus trifurcaten Achsen, mit einem apikalen amplexicaulen fächerförmigen serraten Blatt. Diese Blätter zeigen eine flabellate bis acrodrome-paralellodrome Aderung mit Haupt- und Nebenadern und transversale Adern 3. Ordnung. Diese Merkmale sind typisch für Monocotyledone. Allerdings weist dieses Taxon einige Merkmale auf, die weder bei rezenten noch fossilen Monocotyledonen beobachtet werden. Sie müssen als besondere Anpassungen an einen (saisonal) trockenen und vielleicht übersalzenen Lebensraum dieser Pflanze interpretiert werden.

Schlüsselwörter: Pflanzenfossilien, Unterkreide, articulate Achsen, amplexicaul gezähnte Blätter, Brasilien.

\section{Introduction}

The Early Cretaceous Crato Formation contains in addition to ferns, conifers and gnetophytes a variety of angiosperm fossils. About 30 taxa have been recognized and described, partly in a survey paper (Mohr \& Friis 2000), and in more detailed descriptions (Mohr et al. in press, Mohr $\&$ Friis in prep.). All of these remains are considered to belong to the dicotyledons, mostly to lineages at the magnoliid grade (Mohr \& Friis 2000). Megafossils of monocotyledons have not been described from this locality, nor from other Lower Cretaceous strata in South America. Generally, the Lower and early Upper Cretaceous fossil record of monocots is sparse. Dispersed monocolpate reticulate pollen became more widespread during the Early Cretaceous (Friis et al. 2000). However, in many cases it is not clear whether the pollen belong to monocots or basal magnoliids. Only during the Late Cretaceous do monocot fossil remains become more prominent (Daghlian 1981, Herendeen \& Crane 1995). Therefore, the description of a plant impression from the Crato Formation, with leaves possessing distinct monocotyledonous features, suggesting a presence of monocots in the Early Cretaceous Brazilian flora, adds new aspects on early monocot development.

\section{The fossil record of monocots}

The oldest flowering organs containing in situ pollen which can be putatively placed in the monocots, possibly with affinities to the Alisma-

\footnotetext{
1 Museum für Naturkunde, Invalidenstr. 43, D-10115 Berlin, Germany.

2 Swedish Museum of Natural History, Box 50007, S 10405 Stockholm, Sweden. Received April, accepted June 2002
} 
tales, were described from the Barremian to Aptian of Portugal (Friis et al. 2000). The North American fossils from the Aptian of the Potomac Group, such as Acaciaephyllum are considered to be ambiguous (Gandolfo et al. 2000). But seeds which resemble Epipremnum (Araceae or Alismatales) are known from the Albian of North America (Herendeen \& Crane 1995). Asian Early Cretaceous fossils reported by Samylina (1960) from Siberia and by Cao et al. (1998) from China are either not determinable or now considered to be gnetaleans (Wu et al. 2000). Monocot leaves of late Albian to earliest Cenomanian age were found in Australia and might belong to the Areciflorae (Pole 1999, Greenwood \& Conran 2000).

Unequivocal flowers of monocots are from the Turonian (Gandolfo et al. 1998) of North America (New Jersey). Cretaceous leaves, Zingiberopsis, which are considered to belong to the Zingiberaceae, are from the Cenomanian/Turonian of Bavaria (Knobloch 1979) and the Maastrichtian of Colorado (Hickey \& Peterson 1978). Seeds of the extinct genus Spirematospermum (Musaceae) have been recovered from Upper Cretaceous strata in Europe (Knobloch \& Mai 1986) and from the Campanian of North America (Friis 1988). Also seeds of Typheales have been identified from the German Maastrichtian (Knobloch \& Mai 1986).

During the latest Cretaceous and Early Tertiary the fossil record of monocot megaremains is mostly concentrated on certain groups, such as Arecales, Poales and Cyperales. The mangrove palm Nypa, for example, is reported from South American, Central- and North African Maastrichtian localities (Gee 1990) and reaches during the Paleogene rather high latitudes such as Great Britain and New Zealand (Pole \& Macphail 1996). Other groups, such as the Liliales and Arales are underrepresented, but with certainty demonstrated: Fossil leaves of Philodendron were identified from southeastern North America (Dilcher \& Daghlian 1977) and spadixlike fossils (Acorites) from the Eocene bear numerous florets with bilocular anthers and trilocular ovaries (Crepet 1978). Limnobiophyllum scutatum, a floating aquatic plant from the Eocene of central Alberta, Canada, is considered by the authors to be sister to a clade which includes Spirodela, Lemna and Wolffia (Stockey, et al. 1997). The Eocene Taxon Soleredra rhizomorpha, a permineralized monocotyledon, is considered to belong to the Liliales (Erwin \& Stockey 1991).

\section{Location and geological setting}

The material for this study was recovered from one of the sedimentary basins, the Araripe Basin, of north-eastern Brazil, that were formed in the northern Gondwanan realm by continental rifting and spreading of the Atlantic Ocean. The sequence contains several hundred meters of Jurassic and Cretaceous rocks (Fig. 1), among them the Lower Cretaceous Crato Formation, from where the material is described in this paper. Previously the Crato Formation was included in the Santana Formation as originally defined by Beurlen (1962). The Santana Formation was subsequently subdivided into three members, the Crato, Ipubi, and Romualdo Member (equivalent to the Santana Member) that were later elevated to the rank of formations (Berthou 1990). Together with the Exu Formation, which consists mainly of coarse clastic sediments, these formations were included in the Araripe Group by Martill et al. (1993). The Crato Formation is most basal and consists of organic-rich mudstones and laminated micritic plattenkalk limestones of possibly marginally marine origin (Bechly 1998). The limestone sequence is about $30 \mathrm{~m}$ in thickness, but is variable due to considerable variations in the underlying topography (Martill et al. 1993). Neumann \& Cabrera (1999) gave a detailed analysis of the sedimentary sequence.

Due to lack of good stratigraphic marker fossils and lack of other geological evidence, the age of the sedimentary sequence of the Araripe Group is uncertain. Generally, the Santana Formation s. 1 . is assumed to be of Early to midCretaceous age (Aptian, and/or Albian, and perhaps Cenomanian) (Martill 1993). Sedimentological and palynological studies refined the age estimations for the Crato Member or Formation as late Aptian to early Albian (Berthou 1990, de Lima 1978, Doyle et al. 1982, Pons et al. 1992).

\section{The flora of the Crato Formation}

The Crato strata are extraordinarily rich in plant, invertebrate and vertebrate fossils (Maisey 1991). The fossil plants of the Crato Formation are unusual in comprising not only detached and isolated organs but also larger portions of plants and even completely preserved plants with roots, stems, leaves and flowers in organic connection. Original tissues are in most cases replaced by iron oxides, a process by which original struc- 


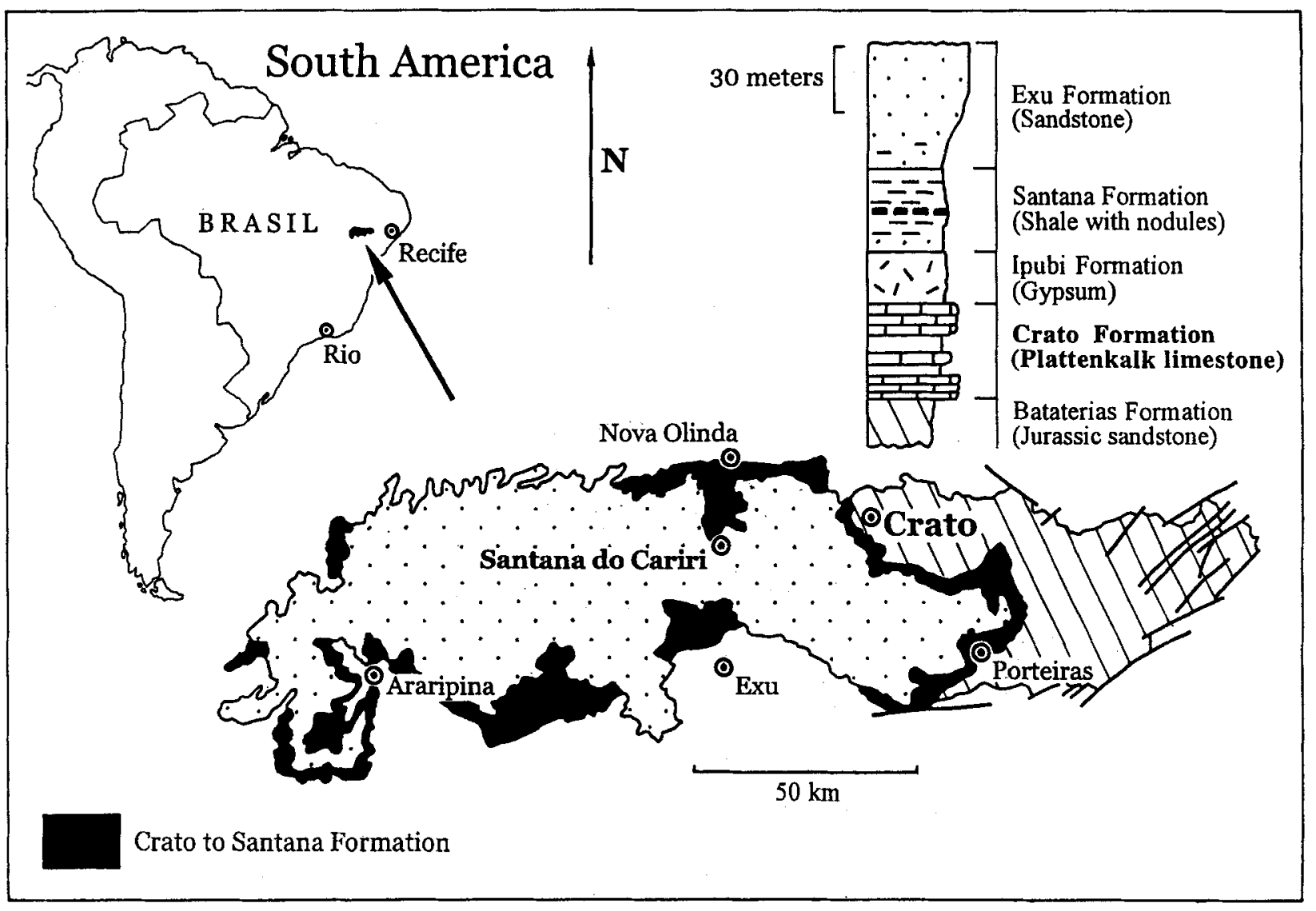

Fig. 1. Geography and Geology of the Araripe Basin, northeastern Brazil, modified from Maisey (1991).

tures are often completely destroyed, but sometimes details of flowering and wood structures are preserved.

Plant fossils from the Crato Formation have been known for many decades, but to date only a few papers on the flora have been published (Barreto et al. 2000, Duarte 1985, Crane 1991, Mohr \& Friis 2000, Mohr et al. in press). The overall diversity is relatively high and the number of taxa is estimated to be about or more than 80 , mainly from terrestrial environments, but also with a few aquatic elements.

The flora comprises a diverse assemblage of pteridophytic plants, including Isoetales (Isoetites), Equisetales (Equisetites) and Filicales (mainly Schizaeaceae), and many non-angiospermous seed plants, including Cycadales, Bennettitales, Coniferales, and Gnetales, as well as a variety of angiosperms. Gnetalean micro- and macrofossils, with partly well preserved wood structures and strobili which contain in situ pollen, constitute a most distinct component of the flora (Pons et al. 1992, de Lima 1980, 1989, Osborn et al. 1993, Wu et al. 2000). Angiosperms are also diverse, with more than 30 taxa (Mohr \& Friis 2000). Dicotyledons are the dominant group (Mohr \& Friis 2000) with a variety of basal characters of the foliage and reproductive organs, often belonging to the magnoliid grade. Monocots have not been previously described.

\section{Material and methods}

The plant fossils described in this paper were gathered at several of about a dozen open cast pits close to the town of Nova Olinda, between Nova Olinda and Santana do Cariri (Fig. 1) in strata which are approximately $1.2 \mathrm{~m}$ thick and about 7-8 meters below ground level (pers. comm. M. Schwickert, 1999). The specimens are preserved as reddish brown impressions on the light yellow-brown limestone slabs. At medium-high to high magnifications details of the leaf venation are well visible.

Five specimens were available for the present study, as well as photographs of six additional fossils. Three of these are housed at the Museum of Natural History, Berlin (holotype MB. Pb. 2000/67, paratype MB. Pb. 2002/798 and the additional specimen MB. Pb. 1999/2301). One specimen is now located at the Kitakyushu Museum and Institute of Natural History (Kitakyushu, Fukuoka, Japan). One small leaf was provided by the Museum of Natural History Stuttgart (SMNS P1919). Photographs of two incomplete specimens from the private collection of H.C. Schenker (Kirchhain) and four specimens of the photo documentation of $M$. and $A$. Schwickert were used for comparison. The specimens were photographed with a Leica M 420 microscope, and a Leica/ Wild MPS 52 photo installation. 

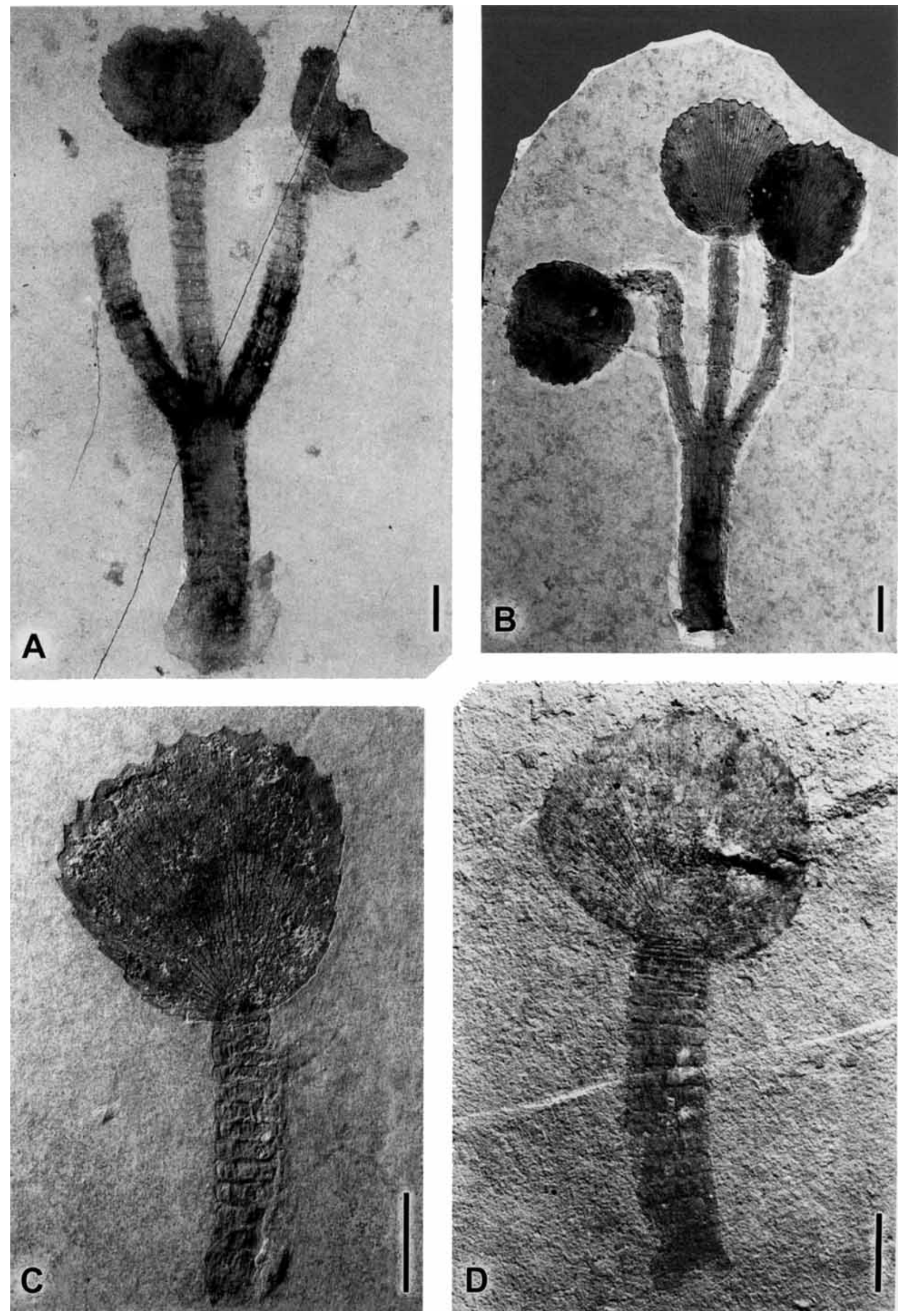
The papers of Hickey (1973) and the "Manual of Leaf Architecture - morphological description and categorization of dicotyledonous and net-veined monocotyledonous angiosperms" by the Leaf Architecture Working Group (1999) were mostly used for the description.

\section{Systematic Palaeontology}

\section{Division Angiospermae Class Monocotyledones Family Unknown}

\section{Trifurcatia n. gen.}

Diagnosis: Trifurcate axes with conspicuous nodes and internodes, each axis bearing a terminal roundish fan-shaped to orbicular leaf, with serrate margin. Venation pattern of these leaves very specific acrodromous to paralellodromous venation with a set of first order veins, irregularly zigzagging secondaries between the first order veins and transverse tertiaries. Teeth are on the apical side concave, on the basal side convex, and spinose. Small, circular to dome shaped bodies are developed between the teeth.

Etymology: Named after the nature of the fossil with its striking trifurcate axes.

Type species: Trifurcatia flabellata $n$. sp.

\section{Trifurcatia flabellata n. sp.}

\section{Diagnosis: Same as for genus.}

Holotype: Specimen MB. Pb. 2000/67 (Figs 2B, $3 A-C, F$, and $4 A, C$ ) of the Museum of Natural History, Institute of Palaeontology, Berlin, Germany.

Paratype: Specimen MB. Pb. 2002/798 (Fig 2A).

Type locality and age: Area of Santana do Cariri, Crato Member, Araripe Basin, Early Cretaceous.

Etymology: Named after the nature of the fossil, indicating that the fossil bears one fanshaped leaf; derived from "flabellum" (lat.) which means fan.
Description: The studied material consists of two larger trifurcate branched axes and three smaller, unbranched axes preserved as impressions. The branched axes (including type specimen MB. Pb. 2000/67, Fig. 2A, B) are $9-11.5 \mathrm{~cm}$ long and consist of specimens that furcate into a median and two lateral axes, of a length of $4-5 \mathrm{~cm}$, each bearing a single apical leaf. Three unbranched subaxes are about 3-5 cm long and probably correspond to either median or lateral axes of the trifurcating specimens.

The main axis is up to $1.5 \mathrm{~cm}(1 \mathrm{~cm})$ in diameter in its basalmost part. The stem does not narrow significantly and the width of the furcating area is only somewhat less than at the base $(1.5-1 \mathrm{~cm})$. The axes exhibit very clearly nodes and internodes, with a distance of about $3 \mathrm{~mm}$. In the upper part of these nodes scars are visible where the former leaves were attached (Fig. 3D). At the top of the axes the distance between the nodes get shorter. The stems exhibit longitudinal ridges, that may indicate the position of vascular bundles (Fig. 2C).

The leaves are broadly oval to orbiculate shaped with a serrate margin. They possess a short sheath (type specimen MB. Pb. 2000/67), but no petiole (Figs 2B, C, 3A, C).

Their size is relatively constant in one specimen, but varies somewhat from one fossil to the other. Length is about $2.5 \mathrm{~cm}$ (varying from $2.2 \mathrm{~cm}, 2.8 \mathrm{~cm}$ and $2.6 \mathrm{~cm}$ in the type specimen MB. Pb. 2000/67) to about $3 \mathrm{~cm}$ in the paratype (MB. Pb. 2002/798). The leaf of the Kitakyushu specimen is about $2.9 \mathrm{~cm}$ long, broadest width is about $2.8 \mathrm{~cm}$. The teeth are about $1-1.5 \mathrm{~mm}$ long, mostly asymmetric, pointing to the tip of the leaf and end in tiny spines, indicating that they are spinose. The number of those teeth is about 25-30. Single roundish to dome-shaped structures, about $0.1-0.2 \mathrm{~mm}$ in diameter, which are interpreted as glands, occur in each depression between the teeth (Fig. 4A, B).

The venation pattern is in principal similarly flabellate as the leaves. There are about $20-25$ main veins which may run into the teeth or in between. Some of these first order veins split in secondaries, sometimes shortly above the base of the leaf, others split near the apex. These secondaries

Fig. 2. Four specimens of Trifurcatia flabellata n. gen. and n. sp. A. Paratype MB. Pb. 2002/798, MfN, Berlin; trifurcate axis, two apically attached leaves preserved. B. Type specimen MB. Pb. 2000/67, MfN, Berlin, trifurcate axis, three apically attached leaves. C. Specimen of the Kitakyushu Museum; axis with one leaf. D. Specimen MB. Pb. 1999/2301, MfN, Berlin; axis with one leaf. Scale bars equal $1 \mathrm{~cm}$. 

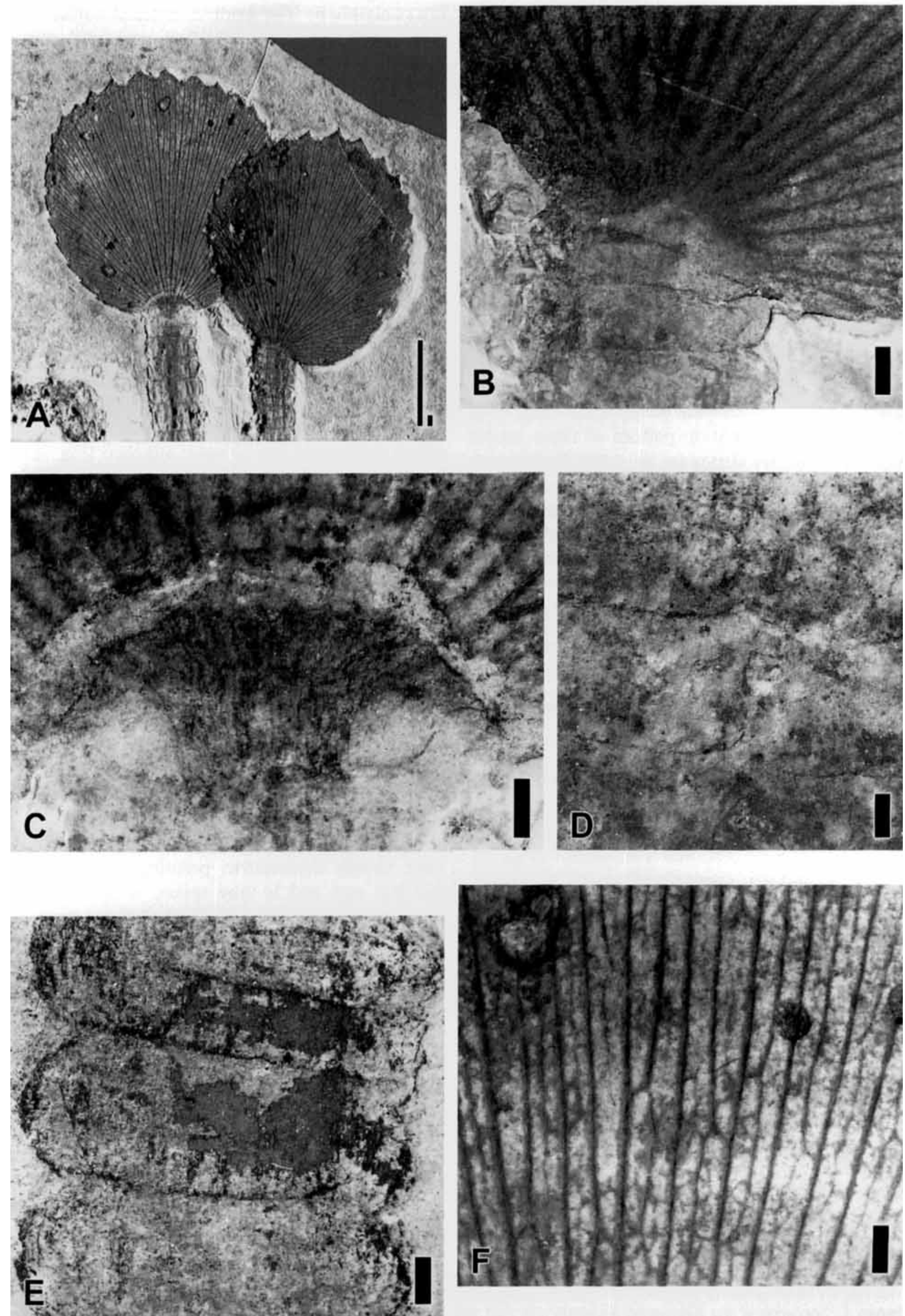

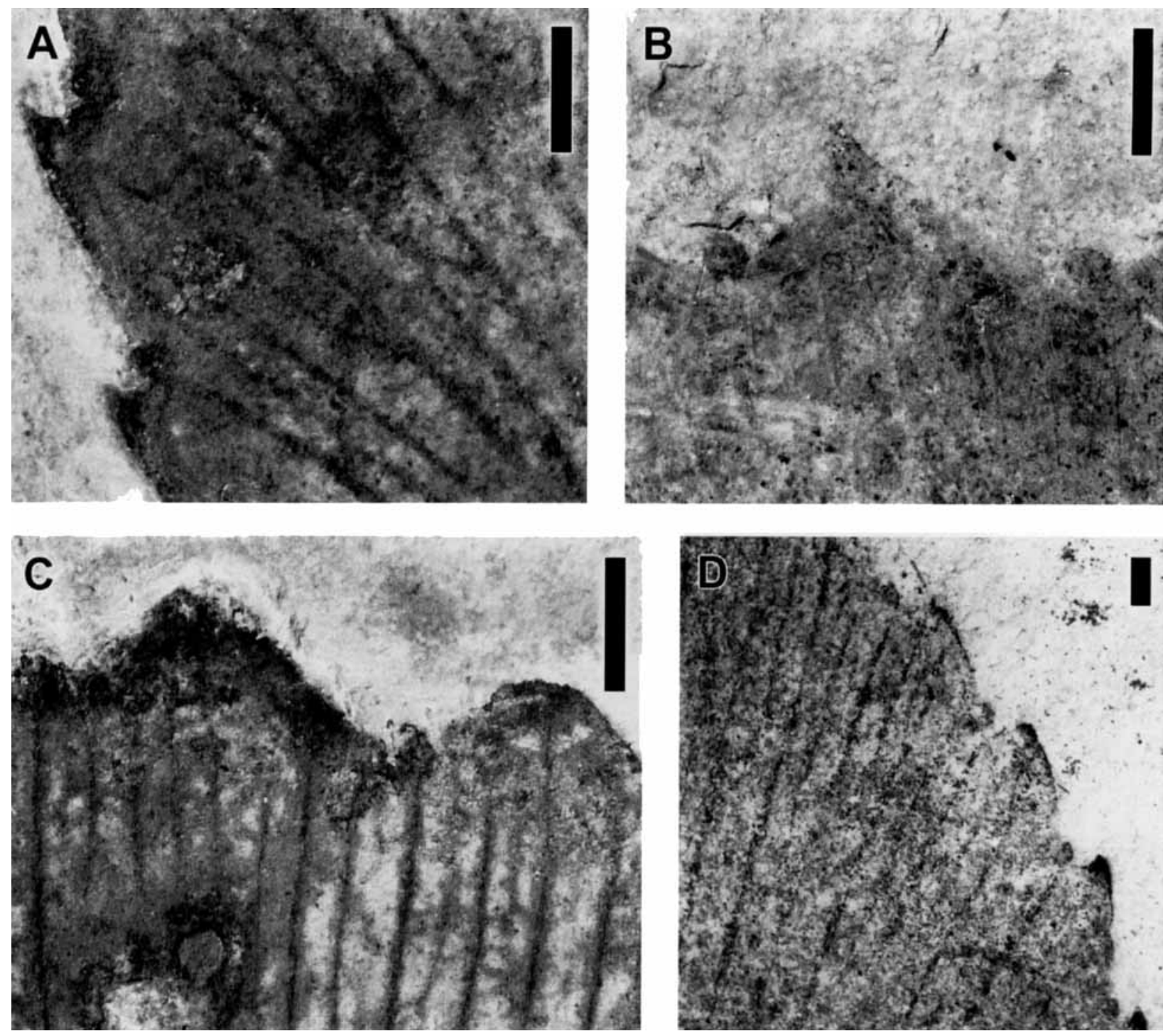

Fig. 4. Venation pattern, serrate leaf margins and putative salt glands of several specimens of Trifurcatia flabellata $\mathrm{n}$. gen. and n. sp. A. Detail of the serrate leaf margin with putative salt glands of the median leaf of type specimen $\mathrm{MB}$. $\mathrm{Pb}$. 2000/67. B. Detail of the serrate leaf margin with putative salt glands of specimen MB. Pb. 1999/2301. C. Leaf margin of the median leaf of type specimen MB. $\mathrm{Pb}$. 2000/67. D. Leaf margin and venation pattern of the median leaf of paratype $\mathrm{MB}$. $\mathrm{Pb}$. $2002 / 798$. Scale bars equal $1 \mathrm{~mm}$.

are irregularly zig-zag shaped. A third set of transverse veins connects primary and secondary veins, creating a reticulate pattern (Figs 3F, 4C). Generally speaking the venation can be characterized as flabellate to acrodromous-parallelodromous with finer cross-veins. All primary and secondary veins lead into a fimbricate vein (Hickey 1973) which runs close to the leaf margin. The leaves appear slightly thickened as inferred by the relatively thick layer of iron-oxide encountered in some parts of these leaves.

\section{Discussion}

\section{Systematic affinities}

The acrodromous to parallelodromous venation pattern of Trifurcatia, with higher order crossveins, the apical fusion of these veins through a marginal vein, the amplexicaul leaf bases and the serrate leaf margin indicate affinity of the fossils to the monocots. Doyle (1973) suggested that fossils with monocotylenoid major venation could

Fig. 3. Magnifications of the type specimen MB. Pb. 2000/67 and specimen MB.Pb. 2002/798. A. Median and left leaves of type specimen MB. Pb. 2000/67. B. Base of the left leaf of type specimen MB. Pb. 2000/67. C. Base of the central leaf of type specimen MB. Pb. 2000/67. D. Leaf scars on the axis of specimen MB. Pb. 1999/2301. E. Detail of the axis of paratype MB. Pb. 2002/798. F. Detail of the median leaf of type specimen MB. Pb. 2000/67. Scale bars equal $1 \mathrm{~cm} / 1 \mathrm{~mm}$ at Fig. 3A, Figs. 3B-F $1 \mathrm{~mm}$. 
be distinguished from other seed plants with "parallel" (basal dichotomizing) venation (e.g., Agathis and Phyllocladus) using three basic morphological features: 1) The longitudinal venation should be differentiated into more than one size or vein orders. 2) Presence of finer (higher order) cross-veins connecting the longitudinal veins. 3) Successive fusion of the longitudinal veins toward the leaf apex. According to Doyle (1973), the last two are especially characteristic and the presence of either of them should be sufficient to suggest a monocot affinity.

Many of the characters observed in the fossil specimens, also occur in other angiosperms and in other non-angiospermous plants:

A dichotomizing venation pattern occurs in several land plant groups, such as ferns (e.g., Dictyophyllum, Dipteridaceae), and extinct seed ferns (Sagenopteris and Glossopteris), conifers (e.g., Agathis, Phyllocladus), and non-monocot angiosperms (Kingdonia, Circaeaster) (Foster 1966), but in these the venation is simple without anastomoses or higher order cross-veins. Vein anastomoses have also been reported for Ginkgo (Arnott 1959) but they occur rarely and most longitudinal veins end freely at the leaf margin.

The vein fusion is important in distinguishing monocots from Gnetales. In monocots (e.g., Tuli$p a)$ and in Trifurcatia, the vein continues throughout the leaf after fusion, whereas the fused veins of Welwitschia seedlings (Rodin 1953, 1958) and of Drewria (Crane \& Upchurch 1987) end in the mesophyll after a short distance. In addition, all known Gnetalean plants have decussate phyllotaxy and leaves with an entire margin.

Besides the venation pattern other features of Trifurcatia are also characteristic for monocots, such as the amplexicaul leafbase and the serrate leaf margin. We thus conclude that an affinity with any other land plant group can be rejected.

\section{Monocot features}

While jointed axes can be seen in several groups of monocots (e.g., Potamogetonaceae), other characters, such as trifurcation of the axes, does not seem to be a regular feature: often monocots branch monopodial, or sympodial. Another character rarely occurring in extant monocots, are the possible (salt) glands at the leaf margin between the teeth. Salt glands are today known from grasses, such as Odyssea paucinervis-a rhizomatious perennial grass, which is widely distributed in southern Africa (Somaru et al. 2002).
These glands are uniformly spread over the surfaces of lamina and sheath.

Phyllotaxy in extant monocots is most often spiral, leaves often with sheaths. In Trifurcatia, only one leaf is found at the end of the axis. Leaf-scars are visible, but it is not clear in which mode these leaves were originally grown. The feature, that except for this one leaf, all the other leaves were shed, is considered to be a very specialized character which might be seen in relation to hot/dry conditions, in order to decrease the area of respiration.

Among the recent monocots Bromeliaceae and members of several genera of the lily family share the character of spiny leaves with Trifurcatia. Aloe has developed also succulence. Aloe plicatilis shares with Trifurcatia a general growth habit, where only a few leaves sit at the end of the axes. However, Aloe plicatilis has a dichotomous furcation pattern, no trifurcations, as seen in Trifurcatia.

Comparison with fossil monocots is difficult, because there are only few Cretaceous taxa described so far and also amomg the younger fossils are none which look the same. The venation type is very similar to the pattern of Zingiberopsis sp. with two sets of parallel veins demonstrated (Hickey \& Peterson 1978) from the Late Cretaceous of North America. With Limnobiophyllum scutatum (Stockey et al. 1997) Trifurcatia n. gen. shares the broad oval to orbicular leaves, and in some ways the venation pattern, especially the fimbricate vein at the leaf margin, but the reticulation is much more developed in Limnobiophyllum. Furthermore the leaf margins of L. are entire, in contrast to Trifurcatia.

We conclude that neither a fossil nor an extant monocotyledon taxon combines all the characters of Trifurcatia n. gen., but it shows several characters which are typical for monocotyledons. Consequently we can not include the new taxon in any of the known families, but we also can not create a new family because the fossils are too fragmentary.

\section{Paleoecology}

The plant shows several features which are interpreted as adaptions to a very specific, probably at least seasonally dry environment. These include the stout stem, the reduced leaf surface by the presence of only a single leaf per axis, the tough nature of the leaves, and the spiny character of the teeth. 
The small bodies between the teeth are interpreted as glands, possibly salt glands, that may have allowed the plant to grow on a hypersaline substrate.

This interpretation is in accordance with sedimentological and other paleontological, especially paleobotanical data. It has been suggested that sedimentation of the Crato strata took place in a lagoon environment (Bechly 1998). Plant material preserved in lagoon deposits, came partly from more distant areas, but partly also from nearby habitats. Many of these fossil plants are still very complete with stems, leaves and roots attached indicating that storm events, especially temporary floods, might have been important for transportation into the depositional basin.

Xeromorphic features in several other plant fossils found in the Crato strata show characters which support the idea of a dry climate. Fernfronds of one currently unnamed taxon are completely covered with simple hairs (Maisey 1991: 417). One of the gnetophyte taxa shows complete reduction of its leaves, and one undescribed dicot angiosperm is covered with oil cells, both signs of harsh, at least seasonally dry conditions.

\section{Conclusions}

1. Trifurcatia flabellata $\mathrm{n}$. gen. and $\mathrm{n}$. sp. represents the oldest vegetative remains of Early Cretaceous monocots and adds new information to the poor fossil record of this group.

2. Trifurcatia possesses a combination of plesiomorphic and apomorphic character states. The structure of the axis with nodes and internodes, and one leaf per node is interpreted as plesiomorphic in monocots. Also the venation pattern is found in extant monocotyledon leaves. Trifurcation of the axes however might be seen as an apomorphic character. Glandlike structures are interpreted as an adaptation which enabled these plants to grow under specific conditions.

3. Considering all the features discussed above, we conclude that this plant must have been adapted to a seasonally dry, maybe even haline environment, an asumption which is in accordance with sedimentological and paleobotanical evidence.

4. Only the vegetative parts of Trifurcatia $\mathrm{n}$. gen. and n. sp. are known at present. Continued study of the Crato fossils should bring to light the reproductive organs necessary to fully reconstruct this Early Cretaceous monocotyledon and clarify its systematic position.

\section{Acknowledgements}

We would like to thank Prof. Dr. H.-P. Schultze (Museum für Naturkunde, Berlin) for his encouragement and support in working with Crato fossils. Mrs. A. and Mr. M. Schwickert (Sulzbachtal) provided specimens of their collection and encouraged a consultation of their photo documentation. Thanks also to Dr. G. Schweigert (Staatliches Museum für Naturkunde Stuttgart) for the loan of one fossil specimen. Mr. H.-C. Schenker (Kirchhain) provided photographs of two specimens. Mrs. C. Radke, Mrs. E. Siebert and Mr. J.- P. Mendau (Museum für Naturkunde, Berlin) took the photographs and compiled the plates and artwork in their usual excellent style and speed. Dr. D. Lazarus (Museum für Naturkunde Berlin) read the English version of the text critically. Thanks also to the two reviewers, Prof. Dr. E. M. Friis (Swedish Museum of Natural History Stockholm) and Prof. Dr. D. H. Mai (Museum für Naturkunde, Berlin) for their valuable comments.

\section{References}

Arnott, H. J. 1959. Anastomoses in the venation of Ginkgo biloba. - American Journal of Botany 46: 405-411.

Barreto, A. M. F., Bernardes-de-Oliveira, M. E. C., Dilcher, D. L., Mandarim-de-Lacerda, A. F. \& Viana, M. S. S. 2000. Early Cretaceous monocarpelar fruit of the Crato Member, Santana Formation, Araripe Basin, Northeastern Brazil. - Geosciencias 5: 121-124.

Bechly, G. 1998. New fossil dragonflies from the Lower Cretaceous Crato Formation of north-east Brazil (Insecta: Odonata). - Stuttgarter Beiträge zur Naturkunde Serie B 264: $1-66$.

Berthou, P. Y. 1990. Le bassin d'Araripe et les petits bassins intracontinentaux voisins (N.E. du Brèsil). Formation et evolution dans le cadre de l'ouverture de l'Atlantique equatorial. Comparaison avec les bassins ouest-Africains situés dans le méme contexte. In Campos, D. de A., Viana, M. S. S., Brito, P. M. \& Beurlen, G. (eds). Atlas do I Simpósio sobre a Bacia do Araripe e Bacias Interiores do Nordeste: 113-134; Crato.

Beurlen, K. 1962. A geologia da Chapada do Araripe. Anais da Academia Brasileira de Ciencias 34(3): $365-370$.

Cao, Z., Wu, S., Zhang, P. \& Li, J. 1998. Discovery of fossil monecotyledons from Yixian Formation, western Liaoning. - Chinese Science Bulletin 43 (3): 230-233.

Crane, P. R. 1991. Fossil Plants. In Maisey, J. G. (ed.). Santana Fossils. An illustrated Atlas: 414-421. T. F. H. Publications, Neptune City, New Jersey.

Crane, P. R. \& Upchurch, G. R. 1987. Drewria potomacensis gen. et sp. nov., an early Cretaceous member of Gnetales from the Potomac Group of Virginia. - American Journal of Botany 74: 1722-1736.

Crepet, W. L. 1978. Investigations of angiosperms from the Eocene of North America: an aroid inflorescence. - Review of Paleaobotany and Palynology 25: 241-252.

Daghlian, C. P. 1981. A review of the fossil record of monocotyledons. - Botanical Review 47: 517-555.

Dilcher, D. L. \& Daghlian, C. P. 1977. Investigations of angiosperms from the Eocene of southeastern North America: Philodendron leaf remains. - American Journal of Botany 64: 526-534. 
Doyle, J. A. 1973. Fossil evidence on early evolution of the monocotyledons. - Quarterly Review of Biology 48: 399-413.

Doyle, J. A., Jardiné, S. \& Doerenkamp, A. 1982. Afropollis, a new genus of early angiosperm pollen, with notes on the Cretaceous palynostratigraphy and palaeoenvironments of northern Gondwana. - Bulletin du Centre de Recherche et Exploration-Production Elf-Aquitaine 6: 39-117.

Duarte, L. 1985. Vegetais fosseis da Chapada do Araripe. BrVIII Congresso brasileiro de Paleontologia, 1983, MME-DNPM, Servicio Geologia, Rio de Janeiro. - Paleontologia e Estratigrafia 2: 557-563.

Erwin, D. M. \& Stockey, R. A. 1991. Soleredera rhizomorpha gen. et sp. nov., a permineralized monocotyledon from the middle Eocene Princeton chert of British Columbia. - Canadian Botanical Gazette 152 (2): 231-247.

Foster, A. S. 1966. Morphology of anastomoses in the dichotomous venation of Circaeaster. - American Journal of Botany 53: 588-599.

Friis, E. M. 1988. Spirematospermum chandlerae sp. nov., an extinct species of Zingiberaceae in the North American Cretaceous. - Tertiary Research 9 (1-4): 7-12.

Friis, E. M., Raunsgaard Peterson, K. \& Crane, P. 2000. Fossil floral structures of a basal angiosperm with monocolpate, reticulate-acolummellate pollen from the Early Cretaceous of Portugal. - Grana 39: 226-239, Stockholm.

Gandolfo, M. A., Nixon, K. C. \& Crepet, W. L. 2000. Monocotyledons: A review of their Early Cretaceous record. In Wilson, K. L. \& Morrison, D. A. (eds). Monocots: Systematics and Evolution. 44-51. CSIRO, Melbourne.

Gandolfo, M. A., Stevenson, D.W. \& Friis, E. M. 1998. Oldest known fossils of monocotyledons. - Nature 394: 532-533.

Gee, C. T. 1990. On the fossil occurrences of the Mangrove palm Nypa. - Proceedings of the Symposium "Paleofloristic and paleoclimatic changes in the Cretaceous and Tertiary", 1989: 315-319, Prague.

Greenwood, D. R. \& Conran, J. G. 2000. The Australian Cretaceous and Tertiary fossil record. In Wilson, K. L. \& Morrison, D. A. (eds.) Monocots: Systematics and Evolution. 52-59, CSIRO, Melbourne.

Herendeen, P. S. \& Crane, P. R. 1995. The fossil history of the monocotyledons. In Rudall, P. J., Cribb, P. J., Cutler, D. F. \& Humphries, C. J. (eds). Monocotyledons: Systematics and Evolution. 1-21, Royal Botanical Gardens, Kew.

Hickey, L. J. 1973. Classifications of the architecture of dicotyledonous leaves. - American Journal of Botany 60: $17-33$.

Hickey, L. J. \& Peterson, R. K. 1978. Zingiberopsis, a fossil genus of the ginger family from Late Cretaceous to early Eocene sediments of Western Interior North America. Canadian Journal of Botany 56: 1136-1152.

Knobloch, E. 1979. Zingiberopsis riggauensis sp.n. - eine interessante Monocotyledone aus der Kreide Bayerns. Vest. Ústredniho ústavu geologického 54 (5): 277-300.

Knobloch, E. \& Mai, D. H. 1986. Monographie der Früchte und Samen in der Kreide von Mitteleuropa. - Rozpravy Ústredniho ústavu geologického 47: 1-219.

Lima, M. R. de 1978. Palinologia da Formaçao Santana (Cretáceo do Nordeste do Brasil). I. Introduçao geologica e descriçao sistematica dos esporos da Subturma Azonotriletes. - Ameghiniana 15 (3-4): 333-365.
- 1980. Palinologia da Formaçao Santana (Cretáceo do Nordeste do Brasil). III. Descriçao sistematica dos polens da Turma Plicates (Subturma Costates). - Ameghiniana 17: $15-47$.

1989 Palinologia da Formaçao Santana (Cretaceo do Nordeste do Brasil). IV. Descriçao sistematica dos polens das Turmas Plicates e Poroses, incertae sedis e Microplancton Marinho. - Ameghiniana 26: 63-81.

Martill, D. M. 1993. Fossils of the Santana and Crato Formations, Brazil. - Palaeontological Association 159: 6-159, London.

Maisey, J. G. (ed.) 1991. Santana Fossils. An Illustrated Atlas. 459 pp., T. F. H. Publications, Neptune City, New Jersey.

Mohr, B. A. R. \& Friis, E. M. 2000. Early angiosperms from the Lower Cretaceous Crato Formation (Brazil), a preliminary report. - International Journal of Plant Science 161 (6 Supplement): S155-S167.

Mohr, B. A. R., Eklund, H. \& Friis, E. M. (in press). Schwickertia florifera nov. gen. nov. sp., a possibly lauralean angiosperm from the Early Cretaceous Crato Formation (Brazil). - Review of Palaeobotany and Palynology.

Neumann, V. H. \& Cabrera, L. 1999. Una nueva propuesta estratigráfica para la tectono secuencia post-rifte de la cuenca de Araripe, noeste de Brasil. In $5^{\mathrm{e}}$ Simpósis sobre o Cretáceo do Brasil Serra Negra, 1999. Boletim de Resumos, Serra Negra, UNESP: 279-285.

Osborn, J. M., Taylor, T. N. \& de Lima, M. R. 1993. The ultrastructure of fossil ephedroid pollen with gnetalean affinities from the Lower Cretaceous of Brazil. - Review of Palaeobotany and Palynology 77: 171-184.

Pole, M. 1999. Latest Albian - earliest Cenomanian monocotyledonous leaves from Australia. - Botanical Journal of the Linnean Society 129: 177-186.

Pole, M. \& Macphail, M. K. 1996. Eocene Nypa from Ragatta Point, Tasmania. - Review of Palaeobotany and Palynology 92: 55-67.

Pons, D., Olivera-Babinsky, M. E. \& de Lima, M. 1992. Les Ephedrales de la Formation Santana, Cretacé inférieur du Bassin d'Araripe (Brésil). IVth International Congress of Palaeobotany, Abstr. Vol.: p. 125, Paris.

Rodin, R. J. 1953. Seedling morphology of Welwitschia. American Journal of Botany 40: 371-378.

- 1958. Leaf anatomy of Welwitschia. I. Early development of the leaf. - American Journal of Botany 45: 90-95.

Samylina, V. A. 1960 . Angiosperms from the Lower Cretaceous of the Kolyma Basin. - Botanical Journal 45: 335-352.

Somaru, R., Naidoo, Y. \& Naidoo, G. 2002. Morphology and ultrastructure of the leaf salt glands of Odyssea paucinervis (Stapf) (Poaceae). - Flora 197: 67-75.

Stockey, R. A., Hoffman, G. W. \& Rothwell, G. W. 1997. The fossil monocot Limnobiophyllum scutatum: Resolving the phylogeny of Lemnaceae. - American Journal of Botany 84 (3): $355-368$.

Wu, S., Duan, S., Mohr, B., Raunsgard Petersen, K. \& Friis, E. M. 2000. Early Cretaceous diversity of Gnetales: Macro- and Mesofossil evidence from China, Brazil and Portugal. - The Sixth Conference of International Organization of Palaeobotany, Qinhuangdao, Abstr. Vol.: p. 37-38, China. 